\title{
Efficacy of biocontrol agents and bactericides for the management of bacterial blight incited by Xanthomonas axonopodis pv. dieffenbachiae in Anthurium andraeanum
}

\author{
M. SUGANYADEVI*, P. RENUKA DEVI AND S. NAKKEERAN
}

Department of Plant Pathology, Centre for Plant Protection Studies, Tamil Nadu Agricultural University, COIMBATORE (T.N.) INDIA

\section{ARITCLE INFO}

Received : 28.01 .2016

Accepted : 21.03 .2016

KEY WORDS :

In vitro, Anthurium, Bactericides and fungicides
*Corresponding author:

Email: suganyadevi08@gmail.com

\begin{abstract}
Bacterial blight of Anthurium incited by Xanthomonas axonopodis pv. dieffenbachiae (XAD) is one of the most serious and devastating disease causes severe losses to cut flower production. In vitro screening of antagonistic B. mojavensis strain KA3 inhibited the growth of $X$. axonopodis pv. dieffenbachiae over an area of $3730 \mathrm{~mm}^{2}$. It was followed by $B$. subtilis isolate BSD4, which inhibited the pathogenic bacteria to an extent of $3430 \mathrm{~mm}^{2}$. In vitro screening with bactericides and fungicides against $X$. axonopodis pv. dieffenbachiae reflected that streptomycin sulphate was most effective in inhibiting the bacterial blight pathogen at $2000 \mathrm{ppm}$ which confers an area of inhibition of $1810 \mathrm{~mm}^{2}$, which was significantly superior over all other treatments and succeeded by $1000 \mathrm{ppm}$ of streptomycin sulphate, which recorded $1254 \mathrm{~mm}^{2}$ area of inhibition against XAD. Screening with gentamycin, indicated that the mean maximum area of inhibition of the bacterial pathogen XAD was $1054 \mathrm{~mm}^{2}$ at 2000 ppm against XAD under in vitro. However, comparison of the efficacy between streptomycin sulphate and gentamycin, indicated that, streptomycin sulphate was highly effective rather than gentamycin. Similarly, fungicides such as copper oxychloride, alliete, isotianil and bromopol (2-bromo 2-nitro propane 1, 3-diol) which had antibacterial activity were tested against $\mathrm{XAD}$ under in vitro.
\end{abstract}

How to view point the article : Suganyadevi, M., Devi, P. Renuka and Nakkeeran, S. (2016). Efficacy of biocontrol agents and bactericides for the management of bacterial blight incited by Xanthomonas axonopodis pv. dieffenbachiae in Anthurium andraeanum. Internat. J. Plant Protec., 9(1) : 292-296. 